\title{
ANALISA PENGARUH TINGKAT INFLASI, TINGKAT SUKU BUNGA SBI, DAN NILAI TUKAR RUPIAH TERHADAP INDEKS HARGA SAHAM GABUNGAN (IHSG) DI BURSA EFEK INDONESIA
}

\author{
Apub Marhen', Irdha Yusra ${ }^{2}$ \\ ${ }^{1,2}$ Sekolah Tinggi Ilmu Ekonomi KBP \\ 1apubmarhen02@gmail.com
}

\begin{abstract}
This study aimed to prove influence of inflasion, interest rates certificates of Bank Indonesia, and exchange rate rupiah on composite stock price index (CSPI) in Indonesia Stock exchange. The periode used in the study was three years from 2015 to 2017.The research design was causal associative and this was a time series study using CSPI at Indonesia Stock Exchange. This data type is documentary. Source data using secondary data. Analysis methods using classical assumtion, multiple regression analysis, and t test.The result there the influence of inflasion, is not influence towar composite stock price index, interest rates of Indonesia Bank is negetive significant toward composite stock price index, and there is not the influece of exchange rate rupiah toward composite stock price index.
\end{abstract}

Keywords: inflation, interest rates on certificates of Indonesia bank, exchange rate rupiah, composite stock price index (CSPI)

\begin{abstract}
ABSTRAK
Penelitian ini bertujuan untuk membuktikan pengaruh Tingkat Inflasi, Tingkat Suku Bunga SBI, dan Nilai Tukar Rupiah terhdap Indeks Harga Saham Gabungan (IHSG) di Bursa Efek Indonesia (BEI). Periode yang digunakan dalam penelitian ini adalah tiga tahun, mulai tahun 2015-2017.Desain penelitian ini adalah penelitian asosiatif kausal. Penelitian ini adalah penelitian time series dengan objek IHSG pada Bursa Efek Indonesia. Jenis data adalah data dokumentasi. Sumber data menggunakan data sekunder, metode analisis menggunakan asumsi klasik, analisis regresi berganda, dan uji t. Hasil penelitian menunjukkan tingkat inflasi tidak berpengaruh secara signifikan terhadap Indeks Harga Saham Gabungan, Suku Bunga SBI berpengaruh secara negativ signifikan terhadap Indeks Harga Saham Gabungan, dan Nilai tukar rupiah tidak berpengaruh terhadap Indeks Harga Saham Gabungan.
\end{abstract}

Kata kunci: inflasi, suku bunga SBI, nilai tukar rupiah, indeks harga saham gabungan (IHSG) 


\section{PENDAHULUAN}

Pasar modal memiki peran besar bagi perekonomian suatu negara, karena pasar modal memiliki dua fungsi sekaligus, yaitu fungsi ekonomi dan fungsi keuangan.

Fungsi Ekonomi sebagai permodalan atau investasi bagi perusahaan dari masyarakat untuk mendapatkan dana, sedangkan fungsi keuangan dari pasar modal adalah, warga masyarakat dapat menanamkan dananya di instrumen pasar modal seperti saham, reksadana, obligasi, dan lain sebagainya.

Secara sederhana, pasar modal dapat didefinisikan sebagai pasar yang memperjual belikan berbagai instrumen keuangan (sekuritas) jangka panjang, baik dalam bentuk utang maupun modal sendiri yang diterbitkan oleh perusahaan (Nasarudin, 2004)

Dengan menggalang dana jangka panjang dari masyarakat dan menyalurkannya ke sektor yang produktif pasar modal dapat di jadikan sarana untuk mempercepat pertumbuhan perekonomian suatu negara, Dan dapat mengurangi ketergantungan terhadap investor asing sehingga mengurangi dana pembangunan dari luar negri.

Investasi di pasar modal memiliki resiko bagi masyarakat. risiko yang terdapat di pasar modal besar kecilnya tergantung dari keadaan suatu negara khususnya dibidang ekonomi,politik dan sosial. selain itu salah satu yang menjadi halangan bagi investor untuk menentukan keputusannya berinvestasi di pasar modal adalah sulitnya untuk mengakses informasi dari pasar modal itu sendiri, yang berpengaruh pada kondisi pasar modal.

Indeks yang menunjukkan pergerakan naik turunnya harga seluruh saham secara umum yang tercatat di bursa efek Indonesia disebut IHSG dan merupakan efek yang menjadi patokan tentang perkembangan kegiatan-kegiatan di pasar modal.

Inflasi, Suku Bunga SBI, Nilai Tukar Rupiah, dan lain sebagainya. merupakan faktorfaktor yang mempengaruhi Indeks harga Saham Gabungan (IHSG).

Inflasi memiliki pengaruh pada IHSG, jika nilai inflasi bertambah tinggi, maka harga barang pokok akan naik dan beban perusahaan juga akan naik karena kenaikan biaya bahan baku/pokok, biaya operasional, dan lain sebagainya yang akan berimbas pada turunnya pendapatan perusahaan dan akan berpengaruh terhadap IHSG.

Investor akan lebih memilih investasi ke pasar uang apabila tingkat suku bunga berada lebih tinggi dari tingkat pengembalian yang di harapkan oleh investor. pengalihan dana dari investor tersebut akan melemahkan nilai IHSG, akan tetapi sebaliknya apabila tingkat suku bunga lebih kecil dari pada tingkat pengembalian yang diharapkan oleh investor, maka investor akan lebih memilih menyimpan dana nya dalam bentuk saham dari pada bentuk deposito berjangka ataupun obligasi.

Nilai Tukar Rupiah berpengaruh terhadap IHSG, apabila nilai tukar rupiah tinggi harga saham akan diturunkan yang bertujuan supaya investor akan membeli saham yang diterbitkan. harga saham di bursa efek tidak selamanya tetap, adakalanya meningkat ataupun menurun, tergantung pada permintaan dan penawaran, dimana terjadi fluktuasi harga saham tersebut menjadikan bursa efek menarik bagi investor.

Banyak faktor yang mempengaruhi pergerakan naik turunnya Indeks Harga Saham Gabunga (IHSG) di Bursa Efek Indonesia, namun pada penelitian ini akan menganalisis pengaruh Inflasi, Suku Bunga SBI dan Nilai Tukar Rupiah terhadap IHSG, faktor-faktor tersebut merupakan faktor internal yang mempengaruhi IHSG, analisis di lakukan guna dapat menjalankan dan memprediksi pergerakan fluktuasi IHSG agar dapat memperoleh hasil yang lebih akurat, dan berguna bagi investor untuk memutuskan arah investasinya.

Hubungan Sebab Akibat Antara Inflasi dengan Indeks Harga Saham gabungan (IHSG). 
Inflasi merupakan salah satu kejadian yang menggambarkan situasi dan kondisi dimana harga barang mengalami kenaikan dan nilai mata uang mengalami pelemahan, dan jika terjadi secara terus menerus, maka akan mengakibatkan pada memburuknya kondisi ekonomi secara menyeluruh serta mampu mengguncang tatanan stabilitas politik suatu Negara (Fahmi, 2011)

Krisna \& Wirawati (2013) dalam penelitian nya menemukan bahwa bahwa secara parsial variabel Inflasi berpengaruh negatif signifikan pada IHSG. Pada saat kondisi inflasi yang tinggi, maka harga barang-barang atau bahan baku akan memiliki kecenderungan untuk naik. kenaikan yang terus menerus tersebut secara umum akan menurunkan daya beli masyarakat, yang dapat mengakibatkan penurunan permintaan terhadap produk barang dan jasa, sehingga dapat mempengaruhi tingkat permintaan perusahaan secara umum, selaku pihak yang menyediakan barang dan jasa. Dan secara langsung akan mempengaruhi omset dari perusahaan, Sehingga performa keuangan akan menurun. Akibatnya pasar akan merespon negatif dari penurunan pendapatan perusahaan, respon negatif dari pasar terhadap saham perusahaan tersebut dapat membuat pasar saham lesu.

Keadaan semacam ini apabila menimpa hampir seluruh perusahaan yang terdaftar di BEI akan melemahkan IHSG selaku composite index di BEI. Namun hal sebaliknya, IHSG akan menguat bila tingkat inflasi mengalami penurunan, karena jika tingkat inflasi turun maka harga-harga barang akan turun dan perusahaan dapat mengoptimalkan labanya dengan baik karena harga produksi yang lebih murah. Berdasarkan uraian tersebut, Inflasi berpengaruh negatif terhadap IHSG.

Berdasarkan argumentasi di atas, hipotesis pertama yang dapat dibangun adalah sebagai berikut:

H1 : Inflasi berpengaruh negatif dan signifikan terhadap Indeks Harga Saham Gabungan (IHSG)

\section{Hubunga Sebab Akibat antara Suku Bunga SBI dengan Indeks Harga Saham Gabungan (IHSG)}

Sertifikat Bank Indonesia merupakan surat berharga atas unjuk dalam rupiah yang diterbitkan oleh Bank Indonesia sebagai pengakuan utang berjangka waktu pendek dan diperjual belikan dengan diskonto.(Siamat, 2005)

Amin (2012) menjelaskan bahwa terdapat hubungan negatif antara tingkat suku bunga dengan pendapatan saham. artinya ketika ada tingkat suku bunga naik maka pendapatan dari sektor saham akan cenderung menurun. Jika tingkat Suku Bunga SBI mengalami peningkatan, maka suku bunga simpanan juga ikut meningkat, sehingga investor lebih tertarik berinvestasi di pasar uang dari pada berinvestasi di pasar saham.

Penurunan permintaan saham akan berdampak pada menurunnya harga saham dan melemahkan nilai IHSG. pelaku pasar modal akan sangat terpengaruh oleh kenaikan suku bunga. kenaikan tingkat suku bunga akan menurunkan harga saham karena dapat meningkatkan beban perusahaan. dari beberapa penjelasan tersebut dapat disimpulkan bahwa, Investor akan cenderung mengalihkan investasinya dari pasar modal ke instrumen pasar uang jika mendapatkan tingkat suku bunga yang tinggi. dengan demikian Suku Bunga SBI akan berpengaruh negatif terhadap IHSG.

Berdasarkan argumen di atas, maka hipotesis kedua yang dapat dibangun adalah sebagai berikut:

H2 : Tingkat Suku Bunga SBI berpengaruh Negatif dan Signifikan Terhadap Indeks Harga Saham Gabungan (IHSG).

Hubungan Sebab Akibat antara Nilai Tukar Rupiah dengan Indeks Harga Saham Gabungan (IHSG) 
USD sesungguhnya seperti barang. Harganya ditentukan oleh besarnya permintaan dan penawaran terhadap USD. harga USD bisa lebih mahal ketika permintaan banyak namun dengan penawaran yang terbatas. penawaran berasal dari hasil devisa negara. dari dana asing yang masuk ke indonesia, baik itu melalui pasar uang dan modal ataupun penanaman modal langsung ke proyek-proyek yang ada di Indonesia. USD juga bisa diperoleh melalui aktivitas pariwisata ataupun hasil ekspor.

Menurut Oktavia (2005) dalam penelitiannya menemukan bahwa secara parsial ada pengaruh negatif dan signifikan antara nilai tukar rupiah pada IHSG di bursa efek Jakarta periode 2003-2005. Artinya adanya pihak yang harus bayar hutang dalam bentuk USD akan meningkatkan permintaan terhadap USD, dan ada juga yang mesti membayar barang impor ataupun penyebab lain seperti spekulasi, Namun, salah satu yang terkait dengan pasar saham adalah keluarnya investor asing dari pasar saham Indonesia.

Mereka menjual sahamnya dalam bentuk Rupiah, lalu hasil penjualan saham itu ditukarkan ke USD dan kemudian dibawa pulang kembali ke negaranya.jadi, dengan kata lain, ketika investor asing menjual saham, berdampak pada penurunan indeks. lalu hasil jualan saham dibelikan USD. Itu merupakan salah satu penyebab IHSG turun dan nilai Rupiah juga turun.

Berdasarkan argumen di atas, maka hipotesisi ketiga yang dapat dibangun adalah sebagai berikut:

H3 : Nilai Tukar Rupiah berpengaruh Negarif dan Signifikan terhadap Indeks Harga Saham Gabungan (IHSG).

\section{METODE PENELITIAN \\ Data dan Sampel}

Data dan Sampel pada penelitian ini adalah data bulanan mengenai Indeks Harga Saham Gabungan (IHSG), Tingkat Inflasi, Suku bunga SBI, dan Nilai Tukar Rupiah, dengan periode pengamatan 2015-2017. Sampel diambil menggunakan metode total sampling yaitu semua populasi memiliki kesempatan untuk menjadi sampel. Data Indeks Harga Saham Gabungan (IHSG) di peroleh dari situs (idx.co.id) dan data Inflasi,Suku Bunga SBI dan Nilai Tukar Rupiah di peroleh dari situs (bi.go.id). berikut.

Secara rinci variabel penelitian yang digunakan dalam penelitian dapat dilihat dari table

\section{Definisi Operasional Variabel}

\begin{tabular}{llll}
\hline No & \multicolumn{1}{c}{ Variabel } & \multicolumn{1}{c}{ Definisi } & \multicolumn{1}{c}{ Pengukuran } \\
& & \\
\hline \hline 1 & Y ( IHSG) & IHSG adalah suatu nilai yang & $\frac{\Sigma \mathrm{H}_{\mathrm{t}}}{\Sigma \mathrm{H}_{\mathrm{O}}} \times 100$ \\
& digunakan untuk mengukur & $\Sigma \mathrm{H}_{\mathrm{t}}=$ Total harga \\
& kinerja gabungan seluruh & semua saham pada \\
& saham yang tercatat di bursa & waktu yang berlaku \\
& efek. & $\Sigma \mathrm{H}_{\mathrm{O}}=$ Total harga \\
& & semua saham pada \\
& & waktu dasar \\
\hline \hline
\end{tabular}




\begin{tabular}{|c|c|c|c|}
\hline 2 & $\mathrm{X}_{1}$ (Tingkat inflasi) & $\begin{array}{l}\text { Inflasi merupakan salah } \\
\text { satu kejadian yang } \\
\text { menggambarkan situasi } \\
\text { dan kondisi dimana harga } \\
\text { barang mengalami } \\
\text { kenaikan dan nilai mata } \\
\text { uang mengalami } \\
\text { pelemahan }\end{array}$ & $\begin{array}{l}\text { Inflasi }= \\
\frac{\mathrm{IHK}_{\mathrm{n}}-\mathrm{IHK}_{0}}{\mathrm{IHK}} \times 100 \\
\text { Keterangan : } \\
\mathrm{IHK}_{\mathrm{n}}=\text { Indeks Harga } \\
\text { Konsumen Periode } \mathrm{t} \\
\mathrm{IHK}_{\mathrm{o}}=\text { Indeks harga } \\
\text { Konsumen Periode t-1 }\end{array}$ \\
\hline 3 & $\begin{array}{l}\mathrm{X}_{2} \text { (Tingkat Suku } \\
\text { Bunga SBI) }\end{array}$ & $\begin{array}{l}\text { Sertifikat Bank Indonesia } \\
\text { (SBI) pada prinsipnya } \\
\text { adalah surat berharga atas } \\
\text { unjuk dalam rupiah yang } \\
\text { diterbitkan oleh Bank } \\
\text { Indonesia sebagai } \\
\text { pengakuan utang } \\
\text { berjangka waktu pendek } \\
\text { dan diperjualbelikan } \\
\text { dengan diskonto. }\end{array}$ & $\begin{array}{l}\text { Suku Bunga }= \\
\text { persentase dari } \\
\text { pinjaman yang } \\
\text { diperoleh dari } \\
\text { jumlah bunga yang } \\
\text { diterima tiap tahun } \\
\text { dibagi dengan } \\
\text { jumlah pinjaman. }\end{array}$ \\
\hline 4 & $\begin{array}{l}\mathrm{X}_{3} \text { (Nilai tukar } \\
\text { rupiah) }\end{array}$ & $\begin{array}{l}\text { Nilai tukar atau kurs } \\
\text { adalah perbandingan } \\
\text { antara harga mata uang } \\
\text { suatu negara dengan mata } \\
\text { uang negara lain }\end{array}$ & $\begin{array}{l}\text { Nilai tukar rupiah } \\
\text { terhadap dollar } \\
\text { Amerika pada setiap } \\
\text { akhir bulan januari } \\
\text { 2015-desember } \\
\text { 2017. }\end{array}$ \\
\hline
\end{tabular}

Berdasarkan tabel 1, terdapat 4 variabel yang digunakan dalam penelitian ini, variabel tersebut kemudian di analisis menggunakan alat bantu statistik, yaitu Analisis Regresi Linier Berganda. namun sebelum menganalisis lebih lanjut hasil regresi, agar hasil yang diberikan representative (memenuhi persyaratan BLUE-best, linier, unbiased, estimator), maka diperlukan uji asumsi klasik.Adapun persamaan yang digunakan adalah sebagai berikut :

$Y=a+\beta_{1} X_{1}+\beta_{2} X_{2}+\beta_{3} X_{3}+e$

Model statistik ini terdiri dari satu variabel dependen dan tiga variabel independen. Dimana Y adalah Indeks harga Saham Gabungan (IHSG)yang merupakan variabel depemden, $a$ bilangan konstanta, $\mathrm{X}_{1}$ adalah Inflasi, $\mathrm{X}_{2}$ adalah Suku Bunga SBI, dam $\mathrm{X}_{3}$ adalah Nilai Tukar Rupiah. Ketiga variabel tersebut merupakan variabel independen

\section{HASIL DAN PEMBAHASAN \\ Statistik Deskriptif}

Statistik deskriptif memberikan gambaran atau deskripsi data yang dilihat dari nilai minimum, nilai maksimum, nilai rata-rata (mean), dan standar deviasi. Tujuannya untuk mengetahui karakteristik variabel yang dianalisis secara terperinci. Statistik deskriptif ditampilkan dalam tabel berikut: 
Tabel 2

Statistik Deskriptif

\begin{tabular}{lllll}
\hline Variabel & Minimum & Maksimum & Mean & Std.Deviation \\
\hline IHSG & 4.223 & 6.355 & 5.269 & 0.550 \\
Inflasi & 2.79 & 7.26 & 4.57 & 1.499 \\
Suku Bunga SBI & 4.25 & 7.75 & 6.02 & 1.354 \\
Nilai Tukar Rupiah & 12.667 & 14.650 & 13.401 & 0.351 \\
\hline
\end{tabular}

IHSG berada pada titik nilai minimun sebesar 4.223 terjadi pada bulan agustus 2015, hal ini terjadi akibat adanya profit taking jangka pendek yang dilakukan oleh investor sehingga mengakibatkan pelemahan IHSG, namun hal tersebut akan terjadi sesaat saja, sedangkan pada penutupan perdagangan desember 2017 IHSG berada pada 6.355, Nilai rata-rata (mean) IHSG sebesar 5,269 dan standar devisiasi sebesar 0,550 hal tersebut menunjukkan bahwa rata-rata (mean) lebih besar dari standar deviasi yaitu 5,269 > 0,550 yang artinya sebaran data IHSG baik sehingga data IHSG dapat dinilai validitasnya.

Pada bulan agustus 2016 inflasi berada pada nilai minimumnya yaitu sebesar 2,79\%, hal ini menunjukkan bahwa terjadi deflasi sekitar $0,4 \%$ dari bulan sebelumnya dimana tingkat inflasi pada bulan sebelumnya berada di angka 3,21\%, hal ini di akibatkan karena dorongan oleh dua kelompok pengeluaran, yakni kolompok bahan makanan dan transportasi yang mengalami penurunan harga yang cukup tajam.

Sedangkan nilai maksimun inflasi sebesar 7.26\% terjadi pada bulan juli 2015 tingginya tingkat inflasi pada bulan juli 2015 diakibatkan oleh kenaikan tarif angkutan udara yang mengalami kenaikan sebesar $11,02 \%$ hal ini karena kenaikan permintaan jasa angkutan udara pada sebelum dan sesudah hari lebaran. Nilai rata-rata (mean) Inflasi 4,57 dan standar deviasi 1,499 menunjukkan bahwa rata-rata (mean) lebih besar dari standar deviasi yaitu 4,57 > 1,499 yang artinya sebaran data inflasi baik sehingga data inflasi dapat dinilai validitasnya.

Tingkat Suku Bunga SBI pada bulan agustus 2017 sebesar 0,25 basis poin dari sebelumnya 4,75\% menjadi 4,5\%, namun pada bulan september 2017 BI kembali menurunkan tingkat suku bunga SBI sebesar 0,25 basis poin menjadi $4,25 \%$ hal ini menjadikan tingkat suku bunga SBI terendah selama periode 2015-2017.

Sedangkan pada januari 2015 inflasi berada pada tingkat nilai maksimal periode tahun 2015-2017 yaitu sebesar 7,75\%, hal ini dilakukan sebagai salah satu cara untuk meredam tingginya tingkat inflasi akibat kebijakan pemerintah menaikkan harga BBM pada akhir 2014 imbasnya masih terasa hingga akhir 2015. Nilai rata-rata (mean) tingkat suku bunga SBI periode 2015-2017 yaitu sebesar 6,02 dan standar deviasi 1,354 menunjuukan rata-rata (mean) lebih besar dari standar deviasi yaitu 6,02>1,354 yang artinya sebaran data tingkat suku bunga SBI baik sehingga dapat dinilai validitasnya.

Nilai tukar rupiah terus mengalami pelemahan selama tahun 2015 nilai tukar rupiah berada pada angka 12.667 pada januari 2015 melemah menjadi 13.787 pada akhir desember 2015, rupiah bahkan sempat melemah di angka 14.650 pada september 2015 yang merupakan nilai terendah rupiah selama periode 2015-2017.

Pelemahan rupiah diakibatkan oleh faktor eksternal karena dolar yang mengalami penguatan adapun penguatan dolar diakibatkan oleh turunnya harga minyak dan sejumlah komoditas. sehingga rupiah tertekan oleh permintaan dollar yang semakin tinggi pada akhir tahun 2015.

Nilai rata-rata (mean) nilai tukar rupiah periode 2015-2017 yaitu sebesar 13.401 dan standar deviasi 0,351 menunjukkan rata-rata (mean) lebih besar dari standar deviasi yaitu $13.401>0.351$ yang artinya sebaran data nilai tukar rupiah baik sehingga dapat dinilai validitasnya. 


\section{Analisis Regresi Linear Berganda}

Analisis regresi berganda digunakan untuk mengetahui pengaruh Inflasi $\left(\mathrm{X}_{1}\right)$, Suku Bunga SBI $\left(\mathrm{X}_{2}\right)$ dan Nilai tukar Rupiah $\left(\mathrm{X}_{3}\right)$ terhadap Indeks Harga Saham Gabungan (Y) Analisis ini diolah dengan menggunakan SPSS. Hasil regresi dapat dilihat pada tabel di bawah ini.

Tabel 3

Hasil Uji Regresi Linear Berganda

\begin{tabular}{lllll}
\hline Variabel & $\begin{array}{l}\text { Koefisien } \\
\text { Regresi }(\boldsymbol{\beta})\end{array}$ & $\boldsymbol{t}_{\text {hitung }}$ & Sig & Keterangan \\
\hline Konstan & 2.780 & & & \\
Inflasi & -0.045 & -0.778 & 0.443 & Tidak Signifikan \\
SBI & -0.330 & -4.551 & 0.000 & Signifikan \\
Nilai Tukar & -0.051 & -0.397 & 0.694 & Tidak Signifikan \\
Rupiah & & & & \\
\hline$t_{\text {tabel }}=2.030$ & & & & \\
$\alpha \quad=05$ & & & & \\
\hline \hline
\end{tabular}

Berdasarkan tabel di atas, diperoleh persamaan regresi linier berganda sebagai berikut : IHSG $=2.780$ - 0,045Inflasi - 0,330SBI - 0,051Nilai tukar

Hasil Pengujian Analisis Regresi Linear Berganda menunjukkan Nilai konstanta (estimasi) Indeks Harga Saham Gabungan (IHSG) sebesar 2.780. Nilai konstan ini menunjukkan bahwa apabila tidak ada variabel tingkat inflasi $\left(\mathrm{X}_{1}\right)$, tingkat suku bunga SBI $\left(\mathrm{X}_{2}\right)$ dan nilai tukar Rupiah $\left(\mathrm{X}_{3}\right)$, maka nilai Indeks Harga Saham Gabungan (IHSG) sebesar 2.780 .

Nilai parameter atau koefisien regresi $\beta_{1}$ dari variabel Inflasi $\left(\mathrm{X}_{1}\right)$ sebesar 0.045 dan bertanda negatif,ini menunjukkan apabila setiap variabel tingkat inflasi $\left(\mathrm{X}_{1}\right)$ meningkat $1 \%$ maka Indeks Harga Saham Gabungan (IHSG) akan menurun sebesar 0,045 poin, dengan asumsi variabel yang lain tetap.

Nilai parameter atau koefisien regresi $\beta_{2}$ dari variabel Suku Bunga SBI $\left(\mathrm{X}_{2}\right)$ sebesar 0,330 bertanda negatif, ini menunjukkan apabila setiap variabel tingkat suku bunga SBI $\left(\mathrm{X}_{2}\right)$ meningkat 1\% maka Indeks Harga Saham Gabungan (IHSG) akan menurun sebesar 0,330 poin, dengan asumsi variabel yang lain tetap.

Nilai parameter atau koefisien regresi $\beta_{3}$ dari variabel Nilai Tukar Rupiah $\left(\mathrm{X}_{3}\right)$ sebesar 0,051 bertanda negatif, ini menunjukkan apabila setiap variabel nilai tukar Rupiah $\left(\mathrm{X}_{3}\right)$ menguat 1\% maka Indeks Harga Saham Gabungan (IHSG) akan melemah 0,051 poin, dengan asumsi variabel yang lain tetap

\section{Hasil Pengujian Hipotesis \\ Hasil Uji t}

Pengujian terhadap hasil regresi dilakukan dengan menggunakan uji statistik t.Uji $t$ bertujuan untuk mengetahui Suku Bunga SBI, Inflasi, dan Nilai Tukar Rupiah secara parsial terhadap IHSG. pengujian ini dilakukan pada tingkat keyakinan 95\%, berikut hasil pengujian uji t. 


\section{Tabel 4}

Hasil uji t Tingkat Inflasi $\left(X_{1}\right)$, Tingkat Suku Bunga SBI $\left(X_{2}\right)$ dan Nilai Tukar Rupiah

$\left(\mathrm{X}_{3}\right)$ terhadap IHSG (Y)

\begin{tabular}{|c|c|c|}
\hline Hipotesis & Nilai & Status \\
\hline $\begin{array}{l}\text { Tingkat Inflasi berpengaruh negatif dan } \\
\text { signifikan terhadap Indeks Harga Saham } \\
\text { Gabungan (IHSG). }\end{array}$ & $\begin{array}{l}t_{\text {hitung }}=-0.778 \\
\text { Sig }=0.443 \\
t_{\text {tabel }}=2.030\end{array}$ & $\begin{array}{l}H_{0}=\text { diterima } \\
H_{a}=\text { ditolak }\end{array}$ \\
\hline $\begin{array}{l}\text { Tingkat suku bunga SBI berpengaruh negatif } \\
\text { dan signifikan terhadap Indeks Harga Saham } \\
\text { Gabungan (IHSG) }\end{array}$ & $\begin{array}{l}t_{\text {hitung }}=-4.551 \\
\text { Sig }=0.000 \\
t_{\text {tabel }}=2.030\end{array}$ & $\begin{array}{l}H_{0}=\text { ditolak } \\
H_{a}=\text { diterima }\end{array}$ \\
\hline $\begin{array}{l}\text { Nilai tukar rupiah berpengaruh negatif dan } \\
\text { signifikan terhadap Indeks Harga Saham } \\
\text { Gabungan (IHSG) }\end{array}$ & $\begin{array}{l}t_{\text {hitung }}=-0.397 \\
\text { Sig }=0.694 \\
t_{\text {tabel }}=2.030\end{array}$ & $\begin{array}{l}H_{0}=\text { diterima } \\
H_{a}=\text { ditolak }\end{array}$ \\
\hline
\end{tabular}

Berdasarkan pengujian Uji t, maka diperoleh hasil sebagai berikut.

Hasil pengujian Uji t pada Inflasi ditemukan bahwa, tingkat inflasi $\left(\mathrm{X}_{1}\right)$ memiliki nilai t hitung sebesar $-0,778$. Nilai ini lebih kecil dari t tabel. $(-0,778<2,030)$. dapat disimpulkan bahwa Inflasi $\left(\mathrm{X}_{1}\right)$ tidak memiliki kontribusi terhadap IHSG (Y).

Dan nilai signifikansi (Sig) 0,443 > 0,05. dengan demikian pengujian menunjukkan $H_{0}$ diterima atau $H_{a}$ ditolak, hasil ini memperlihatkan bahwa variabel tingkat inflasi tidak berpengaruh secara signifikan terhadap Indeks Harga Saham gabungan (IHSG).

Sedangkan Variabel Tingkat Suku Bunga SBI $\left(\mathrm{X}_{2}\right)$ memiliki nilai t hitung sebesar 4,551. nilai ini lebih besar dari t tabel $(-4,551>2,030)$ dapat disimpulkan bahwa Suku Bunga SBI $\left(\mathrm{X}_{2}\right)$ memiliki kontribusi terhadap IHSG (Y). dan nilai signifikansi (Sig) $0,000<0,05$.

Dengan demikian pengujian menunjukkan $H_{0}$ ditolak dan $H_{a}$ diterima. hasil ini memperlihatkan bahwa variabel tingkat suku bunga SBI berpengaruh secara signifikan terhadap Indeks Harga Saham Gabungan (IHSG).

Pada pengujian Uji t Nilai tukar rupiah ditemukan, Variabel Nilai Tukar Rupiah $\left(\mathrm{X}_{3}\right)$ memiliki nilai t hitung sebesar $-0,397$. nilai ini lebih kecil dari t tabel $(-0,387<2,030)$. dapat disimpulkan bahwa Nilai Tukar Rupiah tidak memiliki kontribusi terhadap IHSG (Y). dan nilai signifikansi (Sig) 0,694 > 0,05.

Dengan demikian pengujian menunjukkan $H_{0}$ diterima atau $H_{a}$ ditolak. hasil ini memperlihatkan bahwa variabel tingkat nilai tukar Rupiah tidak berpengaruh secara signifikan terhadap Indeks Harga Saham gabungan (IHSG).

\section{Pembahasan}

Berdasarkan hasil perhitungan penelitian ini, diperoleh hasil bahwa inflasi tidak berpengaruh signifikan terhadap Indeks Harga Saham gabungan (IHSG) periode tahun 2015 2017, namun koefisien regresi tingkat Inflasi bertanda negatif menunjukkan inflasi berpengaruh negatif terhadap Indeks Harga Saham gabungan (IHSG).

Artinya setiap peningkatan inflasi akan menurunkan Indeks Harga Saham Gabungan (IHSG), peningkatan inflasi akan mengakibatkan harga-harga barang menjadi mahal yang pada akhirnya menurunkan laba dan harga saham perusahaan akan ikut mengalami penurunan, hasil yang tidak signifikan disebabkan karena investor tidak melihat variabel inflasi sebagai variabel yang mempengaruhi IHSG, lebih kepada variabel lain karena inflasi yang terjadi pada periode penelitian 2015-2017 masih cukup stabil dan masih tergolong inflasi yang ringan dibawah 10\% jadi masih dapat mendrong perekonomian lebih baik, penelitian ini sesuai dengan penelitian 
Hismendi (2013) yang menemukan bahwa inflasi tidak berpengaruh terhadap Indeks harga Saham Gabunga (IHSG)

Tingkat Suku Bunga SBI berpengaruh negatif dan signifikan terhadap Indeks harga Saham Gabungan (IHSG) periode 2015-2017. Hasil ini menunjukan bahwa peningkatan Suku Bunga SBI akan menurunkan Indeks harga Saham Gabungan (IHSG). hal ini disebabkan karena ketika Suku Bunga SBI menigkat maka investor akan beralih investasi dalam bentuk deposito dan tabungan, sehingga pengalihan dana tesebut akan melemahkan nilai IHSG. penelitian ini sesuai dengan penelitian Amin (2012) yang menemukan bahwa Suku Bunga SBI berpengaruh negetif dan signifikan terhadap Indeks Harga Saham Gabungan (IHSG).

Sedangkan Nilai Tukar Rupiah tidak berpengaruh signifikan terhadap Indeks Harga Saham gabungan (IHSG) periode tahun 2015 - 2017, namun koefisien regresi Nilai Tukar Rupiah bertanda negatif menunjukkan Niai Tukar rupiah berpengaruh negatif terhadap Indeks Harga Saham gabungan (IHSG). apabila Nilai Tukar Rupiah terhadap dolar mengalami kenaikan maka IHSG akan mengalami penurunan, sebaliknya jika Nilai Tukar Rupiah terhadap dollar mengalami penurunan maka IHSG akan mengalami peningkatan. Nilai Tukar Rupiah tidak berpengaruh signifikan terhadap IHSG dikarenakan investor tidak menganggap variabel Nilai Tukar Rupiah sebagai faktor yang mempengaruhi IHSG.

Hal ini disebabkan karna daya beli masyarakat yang masih terjaga, Selain daya beli masyarakat yang masih bagus, juga disebabkan oleh gaya hidup masyarakat menengah ke atas yang terus meningkat. oleh karena itu, daya beli masyarakat dan pertumbuhan ekonomi yang masih stabil bisa mengimbangi fluktuasi kurs. selain itu, pada periode penelitian ini nilai tukar rupiah rata-rata hanya $\mathrm{Rp} 13.401$ sehingga masih dianggap wajar oleh investor di bursa efek, sehingga kurang berdampak pada kenaikan dan penurunan IHSG.

Hasil penelitian ini sesuai dengan penelitian Sari (2014), yang menemukan bahwa Nilai Tukar Rupiah tidak berpengaruh signifikan terhadap Indeks harga Saham gabungan (IHSG).

\section{KESIMPULAN}

Inflasi berpengaruh negatif dan tidak signifikan terhadap IHSG. Setiap peningkatan inflasi akan menurunkan IHSG, begitu juga dengan Nilai Tukar Rupiah juga berpengaruh negatif dan signifikan terhadap IHSG, sedangkan hanya Suku Bunga SBI yang berpengaruh negatif dan signifikan terhadap IHSG.

Pengaruh yang negatif dan tidak signifikan ini menandakan bahwa Investor tidak melihat Inflasi dan Nilai Tukar Rupiah sebagai variabel yang mempengaruhi IHSG periode 2015-2017, hal ini disebabkan tingkat Inflasi dan Nilai Tukar Rupiah yang masih cukup stabil pada periode tersebut. Dan juga karena periode penelitian ini yang cukup singkat yaitu 3 (tiga) tahun, jadi hasil yang diperoleh kurang jelas.

Adanya perbedaan hasil temuan dalam penelitian ini menandakan bahwa untuk menentukan pergerakan Indeks Harga Saham Gabungan (IHSG) tidak cukup hanya melihat satu faktor, butuh perhatian dan analisa megenai faktor-faktor yang lain seperti Indeks negara lain, minyak mentah dan faktor makro ekonomi lainnya. 


\section{DAFTAR PUSTAKA}

Amin, M. (2012). Pengaruh Tingkat Inflasi,Suku Bunga SBI,Nilai krs Dolar dan Indeks dow Jones Terhadap Indeks Harga Saham Gabungan di BEI. Jurnal Skripsi/ Muhammad Zuhdi Amin/ FEB UB/ 2012.

Fahmi. (2011). Analisa Laporan keuangan. Alfa beta. Bandung: Alfabeta.

Hadya, R. (2013a). Pengaruh Harga dan Risiko Saham Terhadap Likuiditas Saham Pada Perusahaan-Perusahaan Yang Terdaftar Di Bursa Efek Indonesia. Jurnal KBP, 1(2), 208231.

Hadya, R. (2013b). Pengaruh Harga dan Risiko Saham Terhadap Likuiditas Saham Pada Perusahaan-Perusahaan Yang Terdaftar Di Bursa Efek Indonesia. Jurnal KBP, 1(2), 208231. Retrieved from https://akbpstie.ac.id/cmsz/medias/file/9. rizka hadya.pdf

Hismendi, Abubakar Hamzah, Said, M. (2013). Analisis pengaruh nilai tukar, sbi, inflasi dan pertumbuhan gdp terhadap pergerakan indeks harga saham gabungan di bursa efek indonesia. Jurnal Ilmu Ekonomi, 1(2), 16-28.

Krisna, A. A. G. A., \& Wirawati, N. G. P. (2013). Pengaruh Inflasi, Nilai Tukar Rupiah, Suku Bunga SBI Pada Indeks Harga Saham Gabungan di BEI. E-Jurnal Akuntansi Universitas Udayana, 3(2), 421-435.

Nasarudin. (2004). Aspek Hukum Pasar Modal Indonesia (p. 13). Prenada Media Group.

Oktavia, A. (2005). pengaruh nilai tukar rupiah/Us\$ dan tingkat suku bunga SBI terhadap IHSG di Bursa efek Jakarta. Analisis Pengaruh Nilai Tukar Rupiah/Us\$ Dan Tingkat Suku Bunga SBI Terhadap IHSG Di Bursa Efek Jakarta Periode 2003-2005.

Saputra, J., \& Martha, L. (2019). Analisis Kinerja Keuangan Dan Nilai Perusahaan, Serta Pengaruhnya Terhadap Harga Saham. INA-Rxiv.

Sari, A. (2014). Pengaruh Tingkat Inflasi, Suku Bunga SBI, Dan Nilai Tukar Rupiah Pada US Dollar Terhadap Pergerakan Indeks harga Saham Gabungan Perusahaan Manufaktur Yang Terdaftar pada Bursa Efek Indonesia Periode Tahun 2010-2013.

Siamat. (2005). Manajemen Lembaga Keuangan, Kebijakan Moneter dan Perbankan. Edisi 5. Fakultas Ekonomi Universitas Indonesia.

Syahfitri, O., \& Dewi, A. S. (2019). Pengaruh Kondisi Fundamental, Inflasi dan Suku Bunga Sertifikat Bank Indonesia terhadap Harga Saham (Studi Kasus Perusahaan Real Estate dan Property yang Terdaftar di Bursa Efek Indonesia). INA-Rxiv, 1-17.

Yulianti, Y. D., \& Yusra, I. (2019). Pergerakan indeks harga saham gabungan sebagai dampak dari variabel makro. INA-Rxiv, 1-11.

Yusra, I. (2019). Composite Indeks Berbasis Variabel Makro: Analisis Kausalitas Data Time Series. Economac, 3(5). 